University of Nebraska - Lincoln

DigitalCommons@University of Nebraska - Lincoln

2015

\title{
A Historical Perspective on Nebraska's Variable and Changing Climate
}

Martha Shulski

William Baule

Crystal J. Stiles

Natalie A. Umphlett

Follow this and additional works at: https://digitalcommons.unl.edu/hprccpubs

Part of the Atmospheric Sciences Commons, Climate Commons, Environmental Indicators and Impact Assessment Commons, Environmental Monitoring Commons, Fresh Water Studies Commons, Hydrology Commons, Meteorology Commons, Natural Resources Management and Policy Commons, Sustainability Commons, and the Water Resource Management Commons

This Article is brought to you for free and open access by the High Plains Regional Climate Center at DigitalCommons@University of Nebraska - Lincoln. It has been accepted for inclusion in HPRCC Personnel Publications by an authorized administrator of DigitalCommons@University of Nebraska - Lincoln. 


\title{
A Historical Perspective on Nebraska's Variable and Changing Climate
}

\author{
Martha D. Shulski, William Baule, Crystal Stiles, and Natalie Umphlett
}

\begin{abstract}
Nebraska is situated at the intersection of the northern and southern Great Plains, exhibiting a dramatic longitudinal gradient for precipitation and humidity, and benefiting from groundwater resources. The continental climate is highly variable temporally both for temperature and precipitation. Our assessment of long-term meteorological observations shows that over the last century the annual average temperature in Nebraska has warmed approximately $0.6^{\circ} \mathrm{C}$, which is similar to the increase in the global average temperature over the same time period. Furthermore, we found minimum temperatures have warmed more than maximum temperatures, and winter and spring show the strongest warming. We found no significant long-term trend in annual precipitation, but seasonal variations exist, namely with wetter springs and falls, and drier winters and summers. The number of days having temperature extremes (both hot and cold) has decreased over time. We found an overall increase in growing season length.
\end{abstract}

Key Words: agriculture, climate change, climate variability, drought, Nebraska

\section{Introduction}

Climate variability and change is a growing concern for agricultural producers, water resource managers, and policy makers, among others, who must make decisions about the future based on climate information. The most recent Intergovernmental Panel on Climate Change (IPCC) assessment report (2013) stated that combined land and ocean surface temperature data indicate that the earth warmed about $0.85^{\circ} \mathrm{C}$ between 1880 and 2012. Projections indicate that, compared to the 1850-1900 average, global surface temperature is likely to increase by at least $3^{\circ} \mathrm{C}$ by the end of the $21 s t$ century. This is a conservative estimate, though a scenario based on the current path of greenhouse gas emissions brings the increase to $10^{\circ} \mathrm{C}$. While projected changes in precipitation are less certain, evidence suggests that precipitation has

Manuscript received for review, 12/22/2014;

accepted for publication, 5/12/2015.

Great Plains Research 25 (Fall 2015):109-120. Copyright $\odot 2015$ by the

Center for Great Plains Studies, University of Nebraska-Lincoln increased over the midlatitude land areas of the Northern Hemisphere, and extreme precipitation events over the midlatitudes are very likely to increase in both frequency and intensity (Hartmann et al. 2013).

The United States has experienced changes in climate similar to those observed globally. The most recent National Climate Assessment (NCA) Report indicated that the average temperature in the United States has increased $0.7^{\circ}-1.1^{\circ} \mathrm{C}$ since 1895 , and average precipitation has increased since 1900 but the increase is unevenly distributed (Melillo et al. 2014). The report also stated that in the last 50 years, some regions in the United States have experienced an increase in severe droughts, intense precipitation, and periods of extremely high temperatures. These changes in the nation's climate are having profound impacts on public health, infrastructure, water resources, agriculture, and ecosystems. The NCA report focuses attention on particular regions (e.g., the Great Plains) and sectors (e.g., agriculture, energy, health).

Nebraska deserves further study in regard to climate change due to its location in the heart of the US Great 
Plains, a region of significant agricultural importance. Far from the moderating influence of an ocean, Nebraska has a continental climate, which features cold winters, hot summers, and high variability from year to year (Shulski et al. 2013). The most notable climate feature in Nebraska is the moisture gradient from east to west, in which the eastern half of the state is classified as humid while the west is classified as semiarid. As such, annual precipitation totals range from $787 \mathrm{~mm}$ in the southeast to $381 \mathrm{~mm}$ in the northwest (1981-2010 average; High Plains Regional Climate Center 2014).

Nebraska experiences considerable climate variability, adding to the uncertainty of producing accurate climate projections for the state. For example, in 2008 Nebraska experienced extensive flooding that also impacted much of the US Midwest. According to a report by the US Department of Commerce (2009), above-normal snowfall during the winter of 2007 and persistent above-normal rainfall during the spring of 2008 were the primary causes of the flooding. During the period of May 21-June 14, 2008, parts of central Nebraska received as much as $500 \mathrm{~mm}$ of rain (US Geological Survey 2010). Then, in 2012, an anomalously warm winter and spring set the stage for the development of a historically intense drought across the state, which led to Nebraska having record warmth and dryness (Umphlett and Fuchs 2014). Impacts were felt across many sectors, including agriculture, vegetation and wildlife, infrastructure, water supply, and transportation. According to the Federal Crop Insurance Corporation of the US Department of Agriculture's Risk Management Agency, indemnity payments due to the drought totaled nearly $\$ 1.49$ billion in Nebraska (quoted in Lubben and Thompson 2013). Experiencing climate extremes in such a short time period leaves Nebraskans wondering if these types of events may become more common as the earth continues to warm.

A climate change report compiled by the University of Nebraska-Lincoln, with input from experts across several sectors (water resources, energy, insurance, communities, ecosystems, and several others), sheds light on observed changes in climate, climate projections, and impacts of climate change in Nebraska (Bathke et al. 2014). The purpose of the report was to provide information to policy makers who are currently or are planning to use climate change information in decision making. The report stated that Nebraska experienced a warming of approximately $0.6^{\circ} \mathrm{C}$ since formal recordkeeping began in 1895 but no discernible increase in mean annual precipitation. The report expressed concerns for possible future decreases in soil moisture and in the snowpack that supplies water to the Platte and Missouri Rivers. An additional concern is the potential for an increase in the frequency and severity of drought. Drought is a normal part of climate in Nebraska, but the severity of the drought of 2012 was exacerbated by the fact that it was the hottest and driest year on record for the state going back to 1895 . Given current emissions scenarios that project increased warming of $2.2^{\circ}-5^{\circ} \mathrm{C}$ by the last quarter of the 21st century, conditions during the drought of 2012 could become a more common feature of Nebraska's climate. Perhaps the most important message conveyed by the report is that the implications of climate change impacts in Nebraska will largely depend on management practices that are implemented in various sectors. Furthermore, those practices will ultimately determine how well Nebraskans adapt and reduce their vulnerability to climate change.

One sector that is directly impacted by climate change and is crucial to the economic vitality of $\mathrm{Ne}$ braska is agriculture. Nebraska ranks second highest nationally in the number of cattle and calves, third highest in the value of sales of cattle and calves, third highest in acres of corn for grain, and fourth highest in total value of agricultural products sold (USDA-NASS 2012). Due to the semiarid climate in the western half of the state and access to water, irrigation is heavily relied upon for successful farming practices. In fact, Nebraska ranks highest in the nation with more than 8 million irrigated acres (USDA-NASS 2013). One could argue, however, that the state's agricultural production could still be vulnerable to climate extremes and climate change. For instance, for locations in Nebraska where irrigation is typically not used (because of higher annual precipitation), Wilhelmi and Wilhite (2002) found a high probability of growing-season crop-moisture deficiency. In addition, these areas have soils with low root-zone water-holding capacity, which increases vulnerability to agricultural drought. Given that severe droughts have increased in the United States (Melillo et al. 2014), Nebraska's agricultural production would benefit from considering how climate change will impact operations.

An issue that is strongly tied to agriculture in the Great Plains, and especially Nebraska, is the continuing decline of groundwater levels in portions of the Ogallala Aquifer. The aquifer underlies eight Great Plains states and is a vital water source for irrigation and other needs. Of these eight states, Nebraska has the most 
acreage overlying the aquifer and withdraws the most water for irrigation (USDA-NRCS 2013). The dependence on the aquifer's water supply to support agriculture in Great Plains states such as Nebraska has contributed to increased groundwater withdrawals, and thus to decreased groundwater supply in some areas, with the most severe declines south of Nebraska. The water management strategy in the state of Nebraska is somewhat unique with the state divided into 23 Natural Resource Districts (NRD, nrdnet.org). Uncertainty in the amount and distribution of precipitation in a changing climate makes it difficult to determine future irrigation demands and how the aquifer will respond to those demands.

Given the aforementioned climate-related issues in Nebraska, we investigated past variability and the magnitude of change in temperature and precipitation in order to place future climate change projections in context. Climate change analyses in the Great Plains to date are broad and generalized (e.g., Shafer et al. 2014), whereas our study analyzes historical climate by season and regionally within Nebraska. The analysis of seasonal changes in climate is useful for identifying spatiotemporal changes in the water cycle, determining shifts in the growing season, and understanding the impacts of extremes. A regional perspective in Nebraska is essential due to the wide climate variability across the state. While we focus on Nebraska, the results of our study may be useful in other areas of the Great Plains, where changes in climate are evident but analyses of these changes on an annual and seasonal basis have not been done.

\section{Methods}

Systematic weather observations that can be used for a trend analysis began in Nebraska (and across the United States) in the middle to late 18oos. At the turn of the 2oth century, there were about 100 observing locations around the state. Currently, there are more than 280 . For the purpose of this study, we consider only those stations with the highest-quality records, that is, those that have complete or nearly complete datasets compiled over long periods of record (1895-2012) and with station inhomogeneities removed (Peterson and Vose 1997). By looking at a long history of these observations, we are able to ascertain variability and changes in climate over time. We used data from two official datasets compiled at long-term observing stations across the state of Nebraska. The two datasets were the United States Historical Climatology Network version 2.0 (USHCN) and the
Global Historical Climatology Network (GHCN), which are archived by the National Centers for Environmental Information (NCEI, formerly NCDC). We analyzed data from USHCN for monthly values (the temporal resolution available) and from GHCN for daily values. We used maximum daily temperature, minimum daily temperature, mean annual temperature, and mean annual precipitation from both datasets. We accessed USHCN data from NCDC and GHCN data from the National Oceanic and Atmospheric Administration Regional Climate Center's Applied Climate Information System (ACIS, www.rcc-acis.org).

To meet the criteria for inclusion in this study, stations had to possess a high-quality (i.e., complete or nearly complete) record for the period 1895-2012. All stations with valid data observations in these years were examined for missing daily values. If we found that more than nine days were missing for a particular variable in a month, we excluded the entire month for that variable. If we excluded more than two months for a variable due to missing daily data, we then excluded the entire year for that variable. If we found more than 10 years were missing from a station's record, we excluded that station from our analyses. We framed seasonal analyses in the context of traditional climatological seasons: winter (December, January, and February), spring (March, April, and May), summer (June, July, and August), and fall (September, October, and November). For seasonal analyses, if we found one month in a season missing, then the entire season for that year was disregarded. For values derived from UsHCN data, if a month, season, or annual value was present for a given year, we included it in the statewide average for that time period to give the most representative statewide value possible. Because data in USHCN and GHCN are quality controlled prior to access by the end user, we did not implement additional quality-control procedures on these data prior to analysis in this study. Due to differing methodologies between USHCN monthly and GHCN daily data, the number of stations available from each dataset differs from one to the other.

Ultimately, for daily values, we found 30 stations in Nebraska that met the criteria for mean minimum temperature, mean maximum temperature, and mean temperature, while 38 stations met the criteria for mean precipitation. For monthly and annual USHCN values, we used 46 stations for mean temperature and precipitation. The spatial distribution of these stations is shown in Figure 1. Because climate is often perceived through extreme 

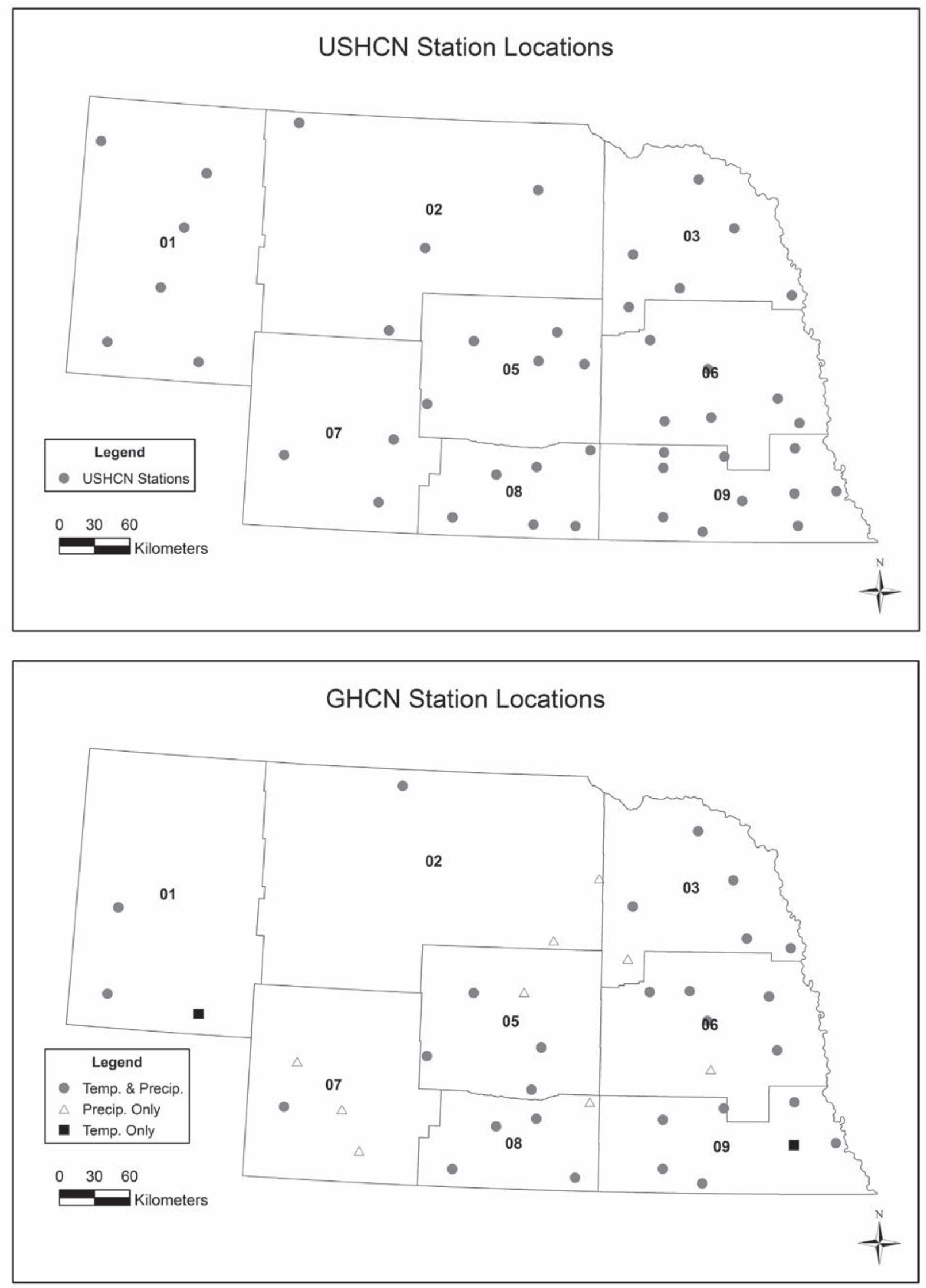

Figure 1. Locations of stations from the USHCN (top) and GHCN (bottom) datasets and climate division boundaries (numbered) in Nebraska. 
events and specific thresholds, we chose specific values to contextualize the climate of Nebraska in addition to mean values of daily and annual temperature and precipitation determined from the monthly USHCN data. We determined annual and seasonal counts for occurrences of maximum temperatures greater than $35^{\circ} \mathrm{C}$ and greater than or equal to $37.8^{\circ} \mathrm{C}$, and minimum temperatures less than or equal to $0^{\circ} \mathrm{C}$ and less than $-17.8^{\circ} \mathrm{C}$. These particular thresholds were utilized since they correspond to those from the most recent National Climate Assessment literature (e.g., Kunkel et al. 2013). For annual and seasonal precipitation, we counted days without measurable precipitation, days with measurable precipitation, and days with precipitation above a particular threshold (3, $6,13,19,25$, and $32 \mathrm{~mm}$ ). We counted days with precipitation observed as a "trace" the same as o $\mathrm{mm}$. For the length of the frost-free (minimum temperature $\geq 0^{\circ} \mathrm{C}$ ) and freeze-free (minimum temperature $\geq-2.2^{\circ} \mathrm{C}$ ) season, we computed the total number of consecutive days above these thresholds for each year. Because some vegetation are frost tolerant and damage occurs at a temperature below $0^{\circ} \mathrm{C}$, we chose two thresholds values to investigate if there were differences in the frost and freeze season length. We determined mean seasonal values for maximum, minimum, and average temperature; and precipitation totals from the USHCN data.

To evaluate potential trends in the mean values and the total values of the seasonal and annual counts of the daily temperature thresholds listed above, we used the Mann-Kendall trend test. Mann-Kendall is a commonly used nonparametric method for testing for the presence of a trend or the nonstationarity of the central tendency of a time series (Wilks 2011). The trends were tested at a confidence interval of $95 \%$. Furthermore, it has been used for the evaluation of trends in hydrometeorological datasets across various climate regions (i.e., Guo et al. 2010; Baule and Shulski 2014). To evaluate the slope of the potential change in the central tendency of the time series, we calculated a least-square regression line for each time series to estimate the change over the analysis period.

\section{Results}

Mean annual temperatures in Nebraska range from about $13^{\circ} \mathrm{C}$ in the far southeast to about $8^{\circ} \mathrm{C}$ in the northern panhandle. Over the last century, we see considerable fluctuation in mean annual temperature with notable warm periods in the 1930 s and 2000s. For many locations 2012 was the warmest year experienced over the instrumental period of record. We found that Nebraska has experienced an overall warming of about $0.6^{\circ} \mathrm{C}$ since 1895 , though the interannual variability is quite high (see Figure 2). Of the 46 stations used in this analysis, 27 exhibit a statistically significant warming ( $p=0.011$ ), while none of the remaining 19 stations exhibit significant cooling.

As with mean annual temperature, precipitation varies strongly from year to year in Nebraska. Notable dry periods of the 1930s and 1950s are prominent in the historical record, with a recent extremely dry year in 2012 (see Figure 3). While we found no significant trend in mean annual precipitation for Nebraska, we found an increase in the number of wet days with 23 of the 38 stations studied (61\%), exhibiting a significant positive trend in annual total counts ( $p=0.0014$ ) of 24 days. (Recall that the number of stations for daily data analyses is slightly lower because daily data, rather than monthly data, are used.) Interestingly, we found essentially no significant trends for the various precipitation thresholds studied (3, $6,13,19,25$, and $32 \mathrm{~mm}$ ). This indicates that the increase in the number of wet days is the result of more days with small (less than $3 \mathrm{~mm}$ ) amounts of precipitation.

More meaningful than the annual changes in some respects are the seasonal variations evident in the climate record, as well as changes in the maximum and minimum daily temperatures. Changes on a shorter temporal scale for these variables often more directly cause impacts when compared to changes in the annual average, such as spring temperature changes influencing planting date for crops. In Nebraska, much of the warming in the state over the last century has occurred at night and during the winter and spring (Figure 4). When categorized by season, we found that winter, spring, and summer have experienced a temperature increase in the average minima of at least $1^{\circ} \mathrm{C}$, double the magnitude of changes in the annual average temperature. For spring and summer, we found that $31(p=$ $0.0054)$ and $33(p=0.0045)$ of the 46 stations, respectively, have a statistically significant warming for the minimum temperatures - the highest number of stations for all variables and seasons studied. We observed the strongest rates of warming for both maximum and minimum temperatures during the winter and spring months with an increase of more than $0.7^{\circ} \mathrm{C}$ for both variables and seasons. For winter, 18 of the 46 stations $(40 \%)$ show a statistically significant warming of the minimum temperature $(p=0.013)$. Warming during the 


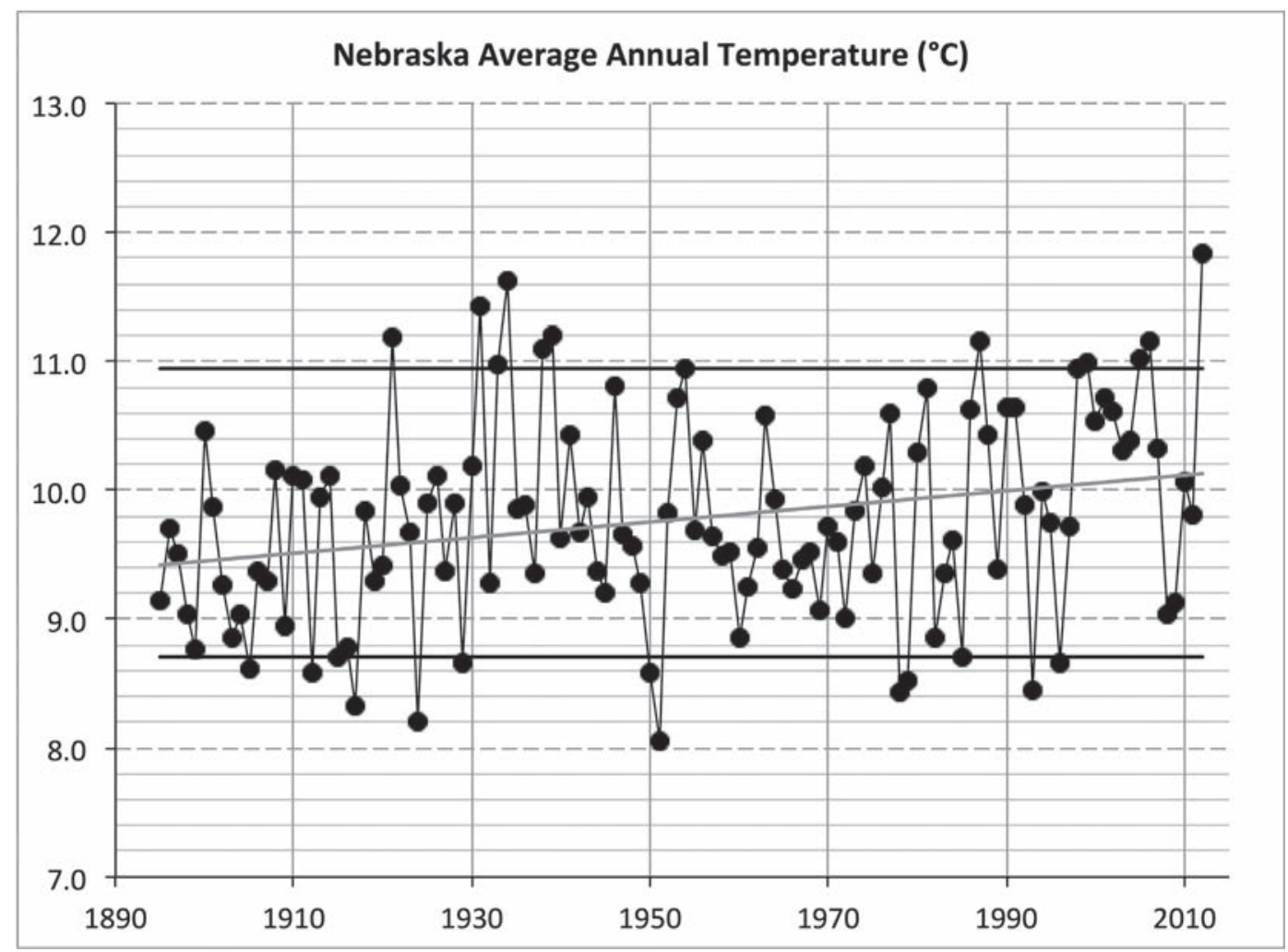

Figure 2. Aggregate average annual temperature $\left({ }^{\circ} \mathrm{C}\right)$ in Nebraska over the period $1895-2012$. The linear trend line and goth and 1oth percentiles are also shown.

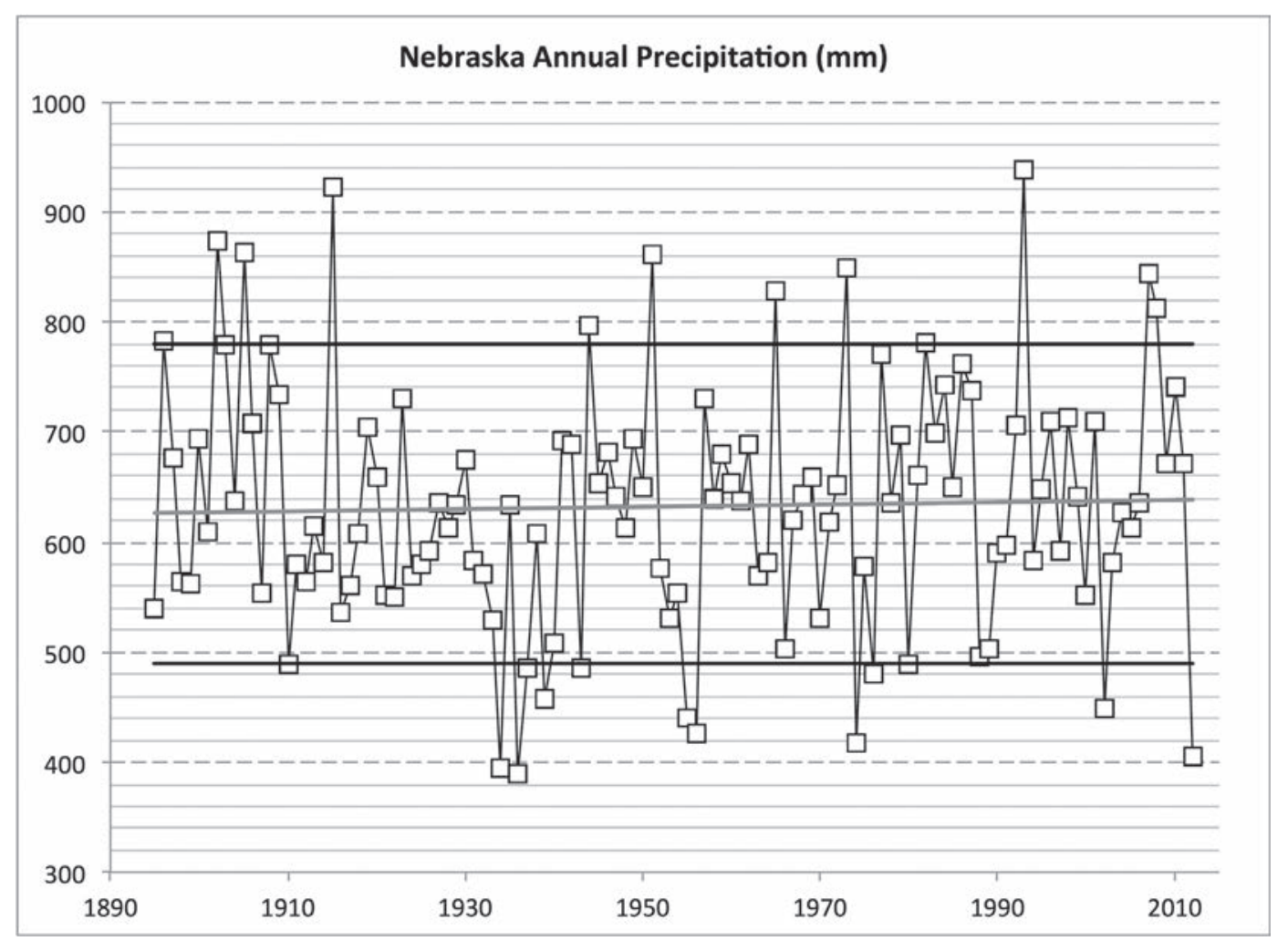

Figure 3. Aggregate total annual precipitation $(\mathrm{mm})$ in Nebraska over the period 1895-2012. The linear trend line and goth and 1oth percentiles are also shown. 


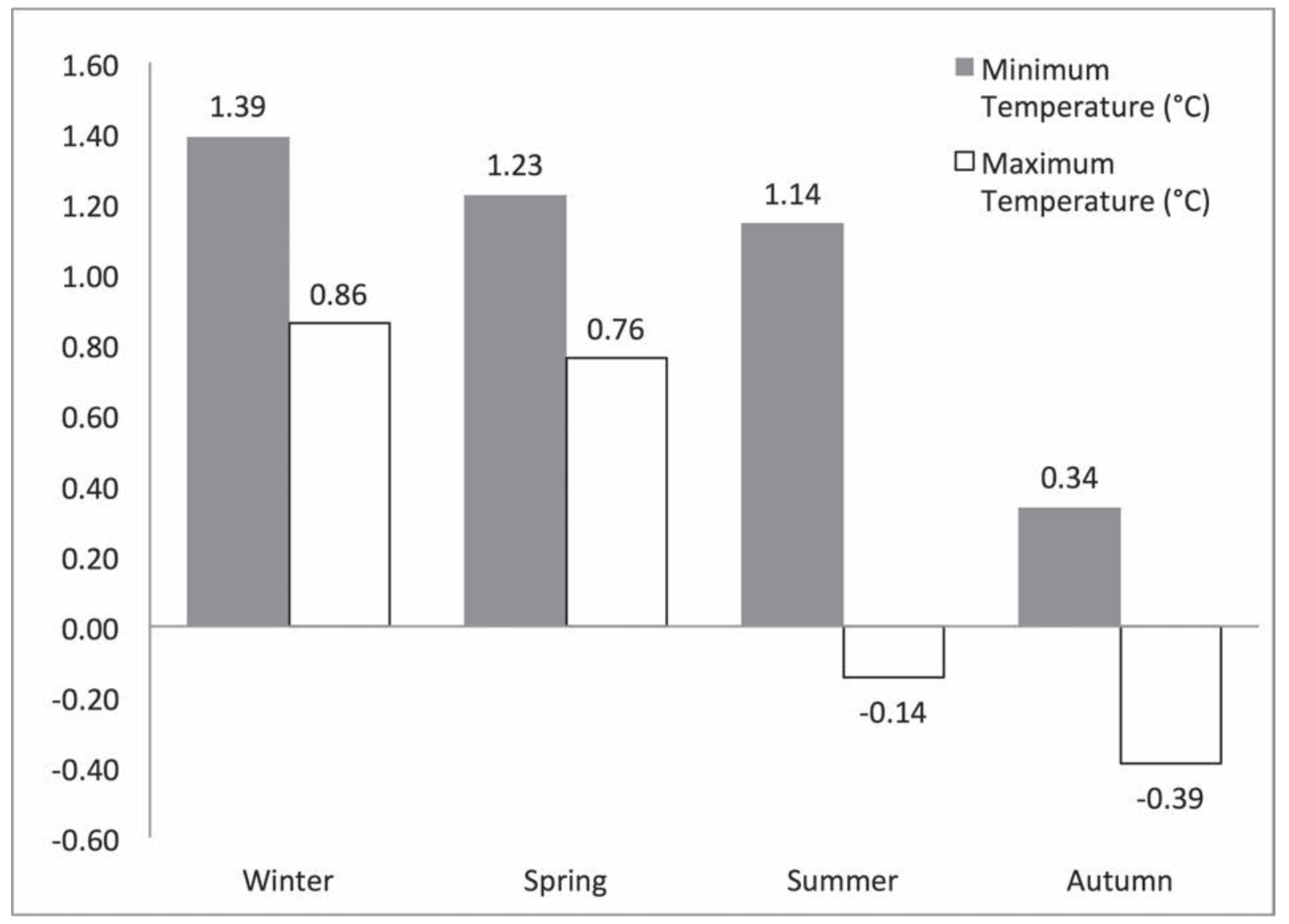

Figure 4. Statewide aggregate total change in maximum and minimum temperature by season over the period 1895-2012.

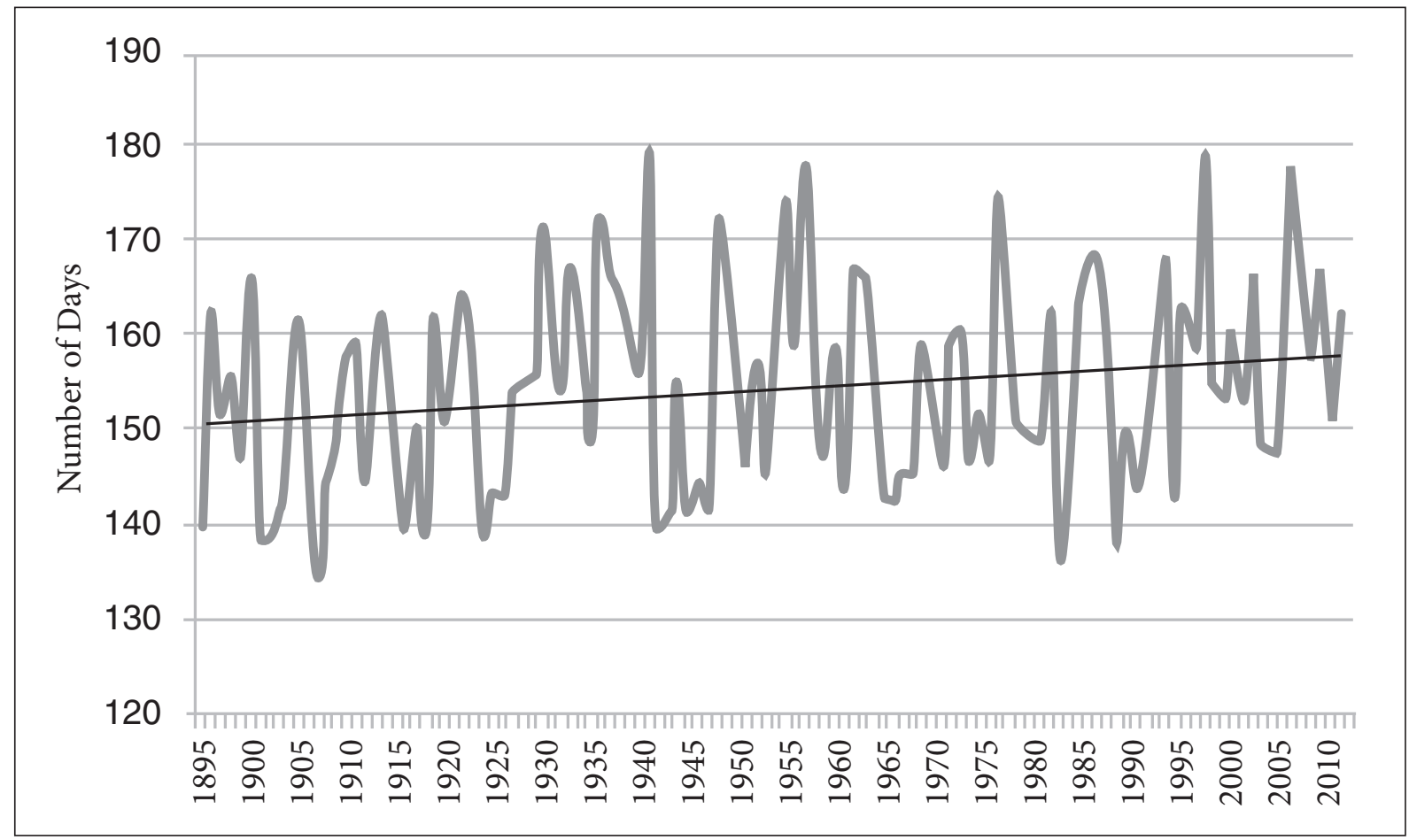

Figure 5. Length of the frost-free season for each year from 1895-2012, including the best-fit linear trend line. 


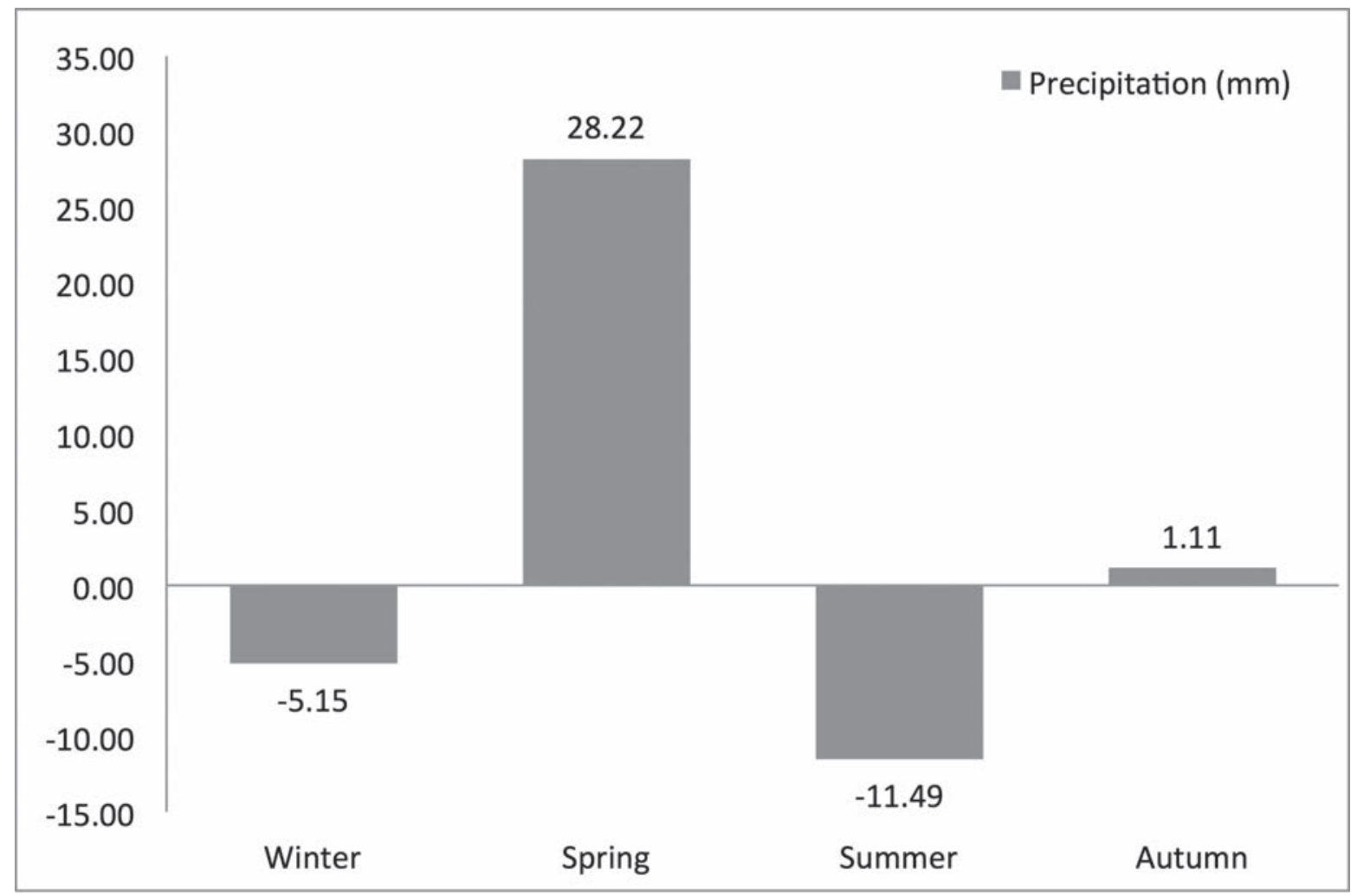

Figure 6. Statewide aggregate total change in precipitation by season over the period 1895-2012.

\section{Precipitation Days in Spring}

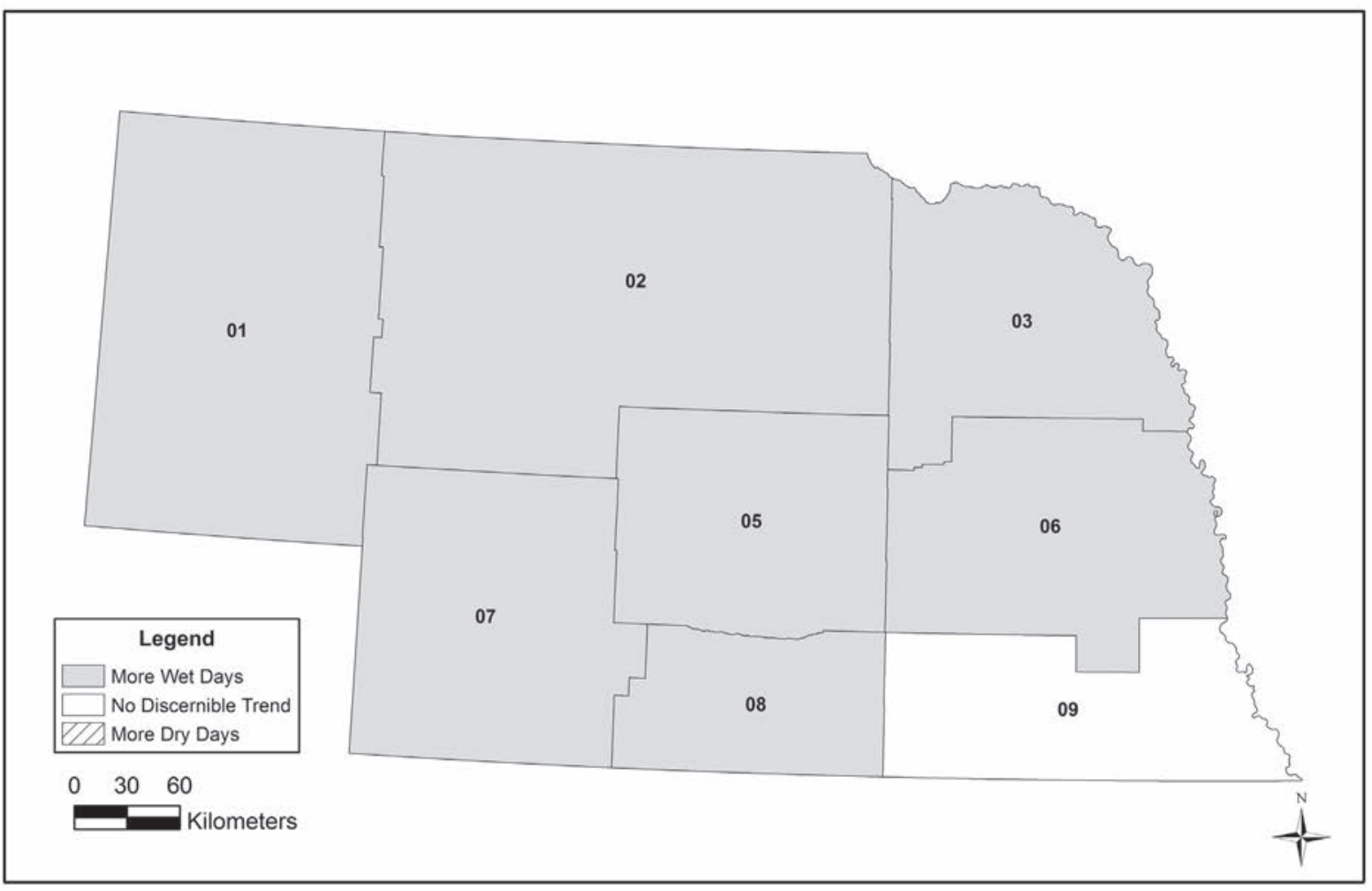

Figure 7. Long-term trends in the number of days with precipitation during spring, shown aggregated by climate division. 
cool seasons is not unique to Nebraska, as similar results have been found nationally and globally (IPCC 2013).

Summer and fall show a warming of minimum temperatures, in addition to a cooling of maximum temperatures. During summer, we found 11 of the 46 stations show significant cooling during the day $(p=0.011)$. In fall, we found 10 stations (22\%) with significant cooling in maximum daytime temperature $(p=0.008)$. These opposing trends (i.e., cooling of maximum temperature and warming of minimum for fall in Nebraska) result in a slight overall cooling during this season with six of the 46 stations showing a statistical significant trend $(p=$ o.011). The similar dichotomy of trends during summer has been discussed for specific regions in prior studies. Irmak et al. (2012) found this result when looking at the Platte River basin of central Nebraska. Mahmood et al. (2013) found that the prevalence of irrigation and subsequent addition of moisture into the atmosphere to be a primary contributing factor in daily temperature changes for the Great Plains. The study found reduced maxima and increased minima for locations that are irrigated as compared to those not irrigated. Thus, irrigation may contribute to changes in summer maxima and minima temperatures in Nebraska.

Extremely warm days, such as those with high temperatures greater than $37.8^{\circ} \mathrm{C}$, have decreased an average of five days per year in Nebraska since 1895. A total of 14 out of 30 stations have statistically significant decreasing trends $(p=0.0066)$ in these extremely warm days. There is a cluster of these stations in the Platte River valley, which is incidentally where the majority of irrigation occurs in Nebraska. Days with a high temperature at or above $35^{\circ} \mathrm{C}$ have also decreased in frequency 11 days overall with 14 of the 30 stations showing a statistically significant trend $(p=0.012)$.

The frequency of occurrence for low temperatures at or below $-17.8^{\circ} \mathrm{C}$ has uniformly decreased over time, as would be expected given the strong significant trend in minimum temperatures. A total of seven of the 30 stations studied show a statistically significant decrease in frequency of six days since 1895 ( $p$ $=0.014$ ). Climate projections indicate that fewer extreme minimum temperatures will occur in the Great Plains as temperatures during the cold seasons warm over time (Kunkel et al. 2013).

Given the importance of agricultural production in Nebraska, we assessed changes in the frost-free season. For the length of the frost-free season (number of consecutive days above $0^{\circ} \mathrm{C}$ ) in Nebraska, we found a statistically significant increase of 19 days since 1895 at nine of the 30 stations studied $(p=0.0042)$. Using a hard freeze threshold of $-2.2^{\circ} \mathrm{C}$, we found eight of the 30 stations had a statistically significant increase $(p=$ 0.015 ) of 15 days in aggregate. As we show in Figure 5 , the growing season length can vary considerably from year to year with statewide aggregate values ranging from a low of 135 to a high of nearly 180 days, a 45 -day variation from shortest to longest. Further investigation on the start and end of the growing season illustrates that the lengthening is occurring at both the start and end of the season. These changes may have important implications in regard to seed selection and crop maturity requirements in agricultural production.

Summer is climatologically the wettest season in Nebraska, which typically experiences high variability from year to year (Figure 6). We found mixed tendencies for the individual stations, where $54 \%$ experienced drying and $46 \%$ wetting. However, these changes are not statistically significant except for one station that was wetter and one drier. We found precipitation to have increased in spring overall statewide, the strongest seasonal precipitation trend in Nebraska with 11 of the 46 stations showing a statistically significant wetting ( $p=$ o.018). Springtime wetting is evident in other parts of the Great Plains, particularly for the eastern Dakotas (Walsh et al. 2014). We also found an increase in the number of wet days in spring with $68 \%$ of stations showing a statistically significant trend of 8 days $(p=0.0089)$. For all areas of Nebraska except for the far southeast region we found an increase in the number of days in spring with measurable precipitation (Figure 7). Given the concurrent rise in temperatures during the spring and a documented increase in soil temperature (Pathak et al. 2012), planting, and therefore seed germination, could begin earlier in the season if fields are workable. One possible impact of the increase in total precipitation and number of wet days, however, could be a delay in the ability to get equipment into fields for planting.

Typically, fall and winter represents a drier time of year in Nebraska, and we see that the long-term data show a slight tendency for wetting during fall with $63 \%$ of the locations showing an increase. However only three locations are statistically significant $(p=0.0025)$. We found winter precipitation to have an overall drying tendency for $65 \%$ (30) of the locations; nine of these are statistically significant trends $(p=0.014)$. For the frequency of extreme precipitation events (those greater than $25 \mathrm{~mm}$ and greater than $32 \mathrm{~mm}$ ) across Nebraska, 
we found no significant long-term statewide increase or decrease in the occurrence of high precipitation amounts (therefore, the results are not shown). The lack of a trend is in contrast to what is occurring for the Midwest as well as the northeast United States (Walsh et al. 2014). In these regions, heavy precipitation events have significantly increased and are projected to further increase in the future.

\section{Conclusions}

Nebraska has experienced an overall warming over the last century, and much of the warming has occurred at night. Winter, spring, and summer minimum temperature trends indicate warming of $1^{\circ} \mathrm{C}$ since 1895. Spring and summer in particular show the strongest trends with $70 \%$ of stations showing a statistically significant warming. During summer and fall, we found a statistically significant cooling for nearly one quarter of the stations in Nebraska. Long-term results for Nebraska are similar to other studies from the United States (Karl et al. 1991; DeGaetano and Allen 2002; Lee et al. 2014). The number of extreme hot days (as defined by days with a high temperature at or greater than $35^{\circ} \mathrm{C}$ and $37.8^{\circ} \mathrm{C}$ ) is variable from year to year, yet $50 \%$ of the stations have a decreasing trend. Studies show similar trends for other areas of the Great Plains and Midwest where agriculture is predominant. The frequency of extreme cold days with low temperatures at or below $-17.8^{\circ} \mathrm{C}$ have shown a slight decrease (six days) at $23 \%$ of the locations. The growing season when viewed in terms of frost-free and freeze-free length shows an overall lengthening of the season. One-third of the locations in Nebraska studied show a statistically significant trend on the order of a two-week increase in length. Obviously this change has implications on crop variety and planting and harvest time frames.

Our precipitation analyses show two important factors on a statewide basis-high interannual variability and little discernible annual long-term trend. When viewed by season, we found the greatest magnitude of change during spring, with an overall wetting. In addition, spring had an increase in the number of days with precipitation (eight days) for nearly $70 \%$ of locations studied in Nebraska. We found winter and fall had a slight drying, with $30 \%$ and $10 \%$ of the locations showing a statistically significant decrease. Summer showed no apparent wetting or drying trend statewide. Heavy precipitation events (daily amounts greater than $25 \mathrm{~mm}$ and $32 \mathrm{~mm}$ ) show no significant change over time statewide. The lack of trend is in contrast to what is documented for the midwestern and northeastern United States, in which an increasing frequency of heavy precipitation has occurred over the 2oth century.

Climate projections of temperature change for the middle and end of the 21st century are for a significant warming - the magnitude of which is much greater than that experienced over the last 117 years. Significant warming would lead to a greater evaporative demand, and the question remains as to how the current agroecosystem landscape will respond and adapt to such a change. Given the nature of Nebraska's climate conditions, residents are generally accustomed to managing high variability from year to year and season to season. However, when extreme events occur back to back, they can be especially difficult to cope with the impacts. A good example of consecutive extremes is the Missouri River flood of 2011 and the Great Plains drought of 2012. Obviously these represent a substantial shift in meteorological conditions and therefore associated impacts. Nebraskans are uniquely positioned to serve as leaders in the United States when it comes to climate resiliency and adaptation. Coping with varying climate conditions is a "normal" aspect of life in the Great Plains, and there is much value in learning from Nebraska's historical variability, trends, and the associated impacts to various sectors and stakeholders.

Martha D.Shulski (mshulski3@unl.edu),Crystal Stiles (cstiles3@unl.edu),NatalieUmphlett (numphlett2@unl.edu), High Plains Regional Climate Center, School of Natural Resources, 711 Hardin Hall, 3310 Holdrege Street, University of Nebraska-Lincoln, Lincoln NE 68583

William Baule (wbaule@umich.edu), University of Michigan Climate Center, Graham Sustainability Institute, University of Michigan, 625 East Liberty Street, Suite 300, Ann Arbor, MI 48104

\section{Acknowledgments}

The authors would like to thank anonymous reviewers of the manuscript for constructive comments. The authors would like to acknowledge the National Oceanic and Atmospheric Administration (contract no. DGO133E-13-CN-0127) for partial support of this project. 


\section{References}

Bathke, D. J., R. J. Oglesby, C. M Rowe, and D. A. Wilhite. 2014. Understanding and Assessing Climate Change: Implications for Nebraska. A Synthesis Report to Support Decision Making and Natural Resource Management in a Changing Climate. Lincoln: University of Nebraska. http://go.unl. edu/climatechange.

Baule, W. J., and M. D. Shulski. 2014. "Climatology and Trends of Wind Speed in the Beaufort/Chukchi Sea Coastal Region from 1979-2009." International Journal of Climatology 34:2819-33.

DeGaetano, A. T., and R. J. Allen, 2002. "Trends in TwentiethCentury Temperature Extremes across the United States." Journal of Climate 15:3188-3205.

Guo, H., M. Xu, and Q. Hu. 2010. "Changes in Near-Surface Wind Speed in China: 1965-2005." International Journal of Climatology 31:349-58.

Hartmann, D. L., A. M. G. Klein Tank, M. Rusticucci, L. V. Alexander, S. Brönnimann, Y. Charabi, F. J. Dentener, E. J. Dlugokencky, D. R. Easterling, A. Kaplan, B. J. Soden, P. W. Thorne, M. Wild, and P. M. Zhai. 2013. "Observations: Atmosphere and Surface." In Climate Change 2013: The Physical Science Basis. Contribution of Working Group I to the Fifth Assessment Report of the Intergovernmental Panel on Climate Change, ed. T. F. Stocker, D. Qin, G. K. Plattner, M. Tignor, S. K. Allen, J. Boschung, A. Nauels, Y. Xia, V. Bex, and P. M. Midgley. Cambridge: Cambridge University Press.

High Plains Regional Climate Center. "30-Year Climate Normals." http://www.hprcc.unl.edu/maps/normals/2014.

IPCC (Intergovernmental Panel on Climate Change). 2013. "Summary for Policymakers." In Climate Change 2013: The Physical Science Basis. Contribution of Working Group I to the Fifth Assessment Report of the Intergovernmental Panel on Climate Change, ed. T. F. Stocker, D. Qin, G. K. Plattner, M. Tignor, S. K. Allen, J. Boschung, A. Nauels, Y. Xia, V. Bex, and P. M. Midgley. Cambridge: Cambridge University Press.

Irmak, S., I. Kabenge, K. E. Skaggs, and D. Mutiibwa, 2012. “Trend and Magnitude of Changes In Climate Variables and Reference Evapotranspiration over 116-yr Period in the Platte River Basin, Central Nebraska, USA." Journal of Hydrology, 420-21, 228-44.

Karl, T. R., R. Kukla, V. N. Razuvayev, M. J. Changery, R. G. Quayler, R. R. Heim Jr., D. R. Easterlin, and C. B. Fu. 1991. "Global Warming: Evidence for Asymmetric Diurnal Temperature Change." Geophysical Research Letters 18:2253-56.

Kunkel, K. E., L. E. Stevens, S. E. Stevens, L. Sun, E. Janssen, D. Wuebbles, M. C. Kruk, D. P. Thomas, M. D. Shulski, N. A. Umphlett, K. G. Hubbard, K. Robbins, L. Romolo, A. Akyüz, T. Pathak, T. R. Bergantino, and J. G. Dobson. 2013. Regional Climate Trends and Scenarios for the US National Climate Assessment, Part 4: Climate of the U.S. Great
Plains. NOAA Technical Report NWSDIS 142-4. Washington DC: National Oceanic and Atmospheric Administration.

Lee, J., S. Li, and R. Lund, 2014. "Trends in Extreme U.S. Temperatures." Journal of Climate 27:4209-25.

Lubben, B., and E. Thompson. 2013. Final Report: The Economic Impact of Crop Insurance Indemnity Payments in Iowa, Nebraska, South Dakota and Wyoming. Prepared for Farm Services Credit of America, March 8, 2013. https://www fcsamerica.com.

Mahmood, R., T. Keeling, S. A. Foster, and K. G. Hubbard. 2013. "Did Irrigation Impact 2oth Century Air Temperature in the High Plains Aquifer Region?" Applied Geography 38:11-21.

Melillo, J. M., T. C. Richmond, and G. W. Yohe, eds. 2014. Highlights of Climate Change Impacts in the United States: The Third National Climate Assessment. US Global Change Research Program. Washington DC: US Government Printing Office.

Pathak, T., K. Hubbard, and M. Shulski. 2012. "Soil Temperature: A Guide for Planting Agronomic and Horticulture Crops in Nebraska." University of Nebraska-Lincoln Institute of Agriculture and Natural Resources NebGuide, G2122, 4 pp.

Peterson, T. C., and R. S. Vose. 1997. "An Overview of the Global Historical Climatology Network Temperature Database." Bulletin of the American Meteorological Society 78 (12): 2837-49.

Shafer, M., D. Ojima, J. M. Antle, D. Kluck, R. A. McPherson, S. Petersen, B. Scanlon, and K. Sherman. 2014. "Ch. 19: Great Plains." In Climate Change Impacts in the United States: The Third National Climate Assessment," ed. J. M. Melillo, Terese (T.C.) Richmond, and G. W. Yohe, 441-61. US Global Change Research Program, doi:10.7930/JoD798BC.

Shulski, M. D., N. A. Umphlett, T. B. Pathak, and K. G. Hubbard, 2013. "Climate Change: What Does It Mean for Nebraska?" University of Nebraska-Lincoln Institute of Agriculture and Natural Resources NebGuide, G2208.

Umphlett, N. A., and B. Fuchs. 2014. Nebraska. In From Too Much to Too Little: How the Midwest Drought of 2012 Evolved Out of One of the Most Devastating Floods on Record in 2011, ed. B. A. Fuchs, D. A. Wood, and D. Ebbeka. NOAA Central Region Drought Assessment.

USDA-NASS. 2012. "2012 Census of Agriculture State Profile, Nebraska.” US Department of Agriculture, National Agriculture Statistics Service, http://www.agcensus.usda.gov/ Publications/2012/Online_Resources/County_Profiles/ Nebraska/cp99031.pdf.

USDA-NASS. 2013. "2013 Farm and Ranch Irrigation Survey." US Department of Agriculture, National Agriculture Statistics Service. http://www.agcensus.usda.gov/ Publications/2012/Online_Resources/Farm_and_Ranch _Irrigation_Survey/frisi3.pdf.

USDA-NRCS. 2013. "Groundwater Irrigation and Water Withdrawals: The Ogallala Aquifer Initiative." US Department of Agriculture, Natural Resource Conservation Service. 
http://www.nrcs.usda.gov/Internet/FSE_DOCUMENTs/ stelprdb1186440.pdf.

US Department of Commerce. 2009. "Central United States Flooding of June 2008." http://www.nws.noaa.gov/om/ assessments/pdfs/central_floodingo9.pdf.

US Geological Survey. 2010. "Flooding in the United States Midwest, 2008.” Professional Paper 1775. http://pubs.usgs.gov/ pp/1775/pdf/pp1775.pdf.

Walsh, J., D. Wuebbles, K. Hayhoe, J. Kossin, K. Kunkel, G. Stephens, P. Thorne, R. Vose, M. Wehner, J. Willis, D. Anderson, S. Doney, R. Feely, P. Hennon, V. Kharin, T. Knutson,
F. Landerer, T. Lenton, J. Kennedy, and R. Somerville. 2014. “Ch. 2: Our Changing Climate." In Climate Change Impacts in the United States: The Third National Climate Assessment, ed. J. M. Melillo, Terese (T.C.) Richmond, and G. W. Yohe, 19-67. US Global Change Research Program, doi:10.7930/JoKW5CXт.

Wilhelmi, O. V., and D. A. Wilhite. 2002. "Assessing Vulnerability to Agricultural Drought: A Nebraska Case Study." Natural Hazards 25:37-58.

Wilks, D. S. 2011. Statistical Methods in the Atmospheric Sciences. Oxford: Academic Press. 